\title{
Exercise Training as Treatment of Nonalcoholic Fatty Liver Disease
}

\author{
Oliver K. Glass ${ }^{1,2, *}$, Akash Radia ${ }^{3}$, William E. Kraus ${ }^{4,5}$ and Manal F. Abdelmalek ${ }^{6}$ \\ 1 Duke Integrative Medicine, Duke University Medical Center, Durham, NC 27705, USA \\ 2 Division of General Internal Medicine, Department of Medicine, Duke University School of Medicine, \\ Durham, NC 27710, USA \\ 3 School of Public Health, Brown University, Providence, RI 02903, USA; akash_radia@brown.edu \\ 4 Duke Molecular Physiology Institute, Duke University School of Medicine, Durham, NC 27710, USA; \\ william.kraus@duke.edu \\ 5 Division of Cardiology, Department of Medicine, Duke University School of Medicine, \\ Durham, NC 27710, USA \\ 6 Division of Gastroenterology \& Hepatology, Department of Medicine, Duke University School of Medicine, \\ Durham, NC 27710, USA; manal.abdelmalek@duke.edu \\ * Correspondence: oliver.glass@duke.edu; Tel.: +1-919-660-6672
}

Received: 5 September 2017; Accepted: 22 September 2017; Published: 24 September 2017

\begin{abstract}
Nonalcoholic Fatty Liver Disease (NAFLD) is a growing health epidemic in developed countries with increased prevalence in obese and diabetic populations. Exercise is an established and essential component of lifestyle modification for NAFLD disease management. Despite numerous studies reporting exercise-mediated improvements in NAFLD, there remains a large gap in our knowledge of how to optimize exercise prescriptions and whether the benefits of exercise extend beyond improvements in liver fat. In this review, we summarize studies that have investigated the independent effects of exercise training on liver enzymes, hepatic fat, and histologic markers in NAFLD. Overall, 12-weeks of aerobic, resistance, the combination of aerobic and resistance, and novel training modalities, including acceleration and hybrid training, significantly improve liver enzymes and hepatic fat. The greatest benefits in NAFLD may occur through the combination of aerobic and resistance training that targets both cardiorespiratory fitness, and mediators of skeletal muscle, known as myokines. Understanding the role of myokines in the beneficial effects of exercise in NAFLD may identify future therapeutic targets that can be modified with tailored exercise prescriptions.
\end{abstract}

Keywords: exercise; NAFLD; NASH; aerobic; resistance; training

\section{Introduction}

Nonalcoholic Fatty Liver Disease (NAFLD) encompasses a clinicopathologic spectrum of disorders ranging from isolated hepatic steatosis (fatty liver) to more progressive nonalcoholic steatohepatitis (NASH), characterized histologically by the presence of necroinflammation, ballooned hepatocytes, and hepatic fibrosis. NAFLD now affects $15-30 \%$ of the general population, with an increased incidence in obese and diabetic populations [1,2]. Of those with NAFLD, $25 \%$ will go on to develop NASH, thereby conferring an increased risk for progressive hepatic fibrosis, the primary determinant of liver related morbidity and mortality for patients with NASH [1,3]. Currently, there are no FDA-approved pharmacologic therapies for NAFL and NASH. Diet and exercise strategies targeting weight loss through an energy deficit remain the cornerstone of disease management [4,5]. Diet-and exercise-induced weight loss $>5 \%$ total body weight improves NAFLD and reverses hepatic necroinflammation and fibrosis [6]. Weight loss, however, is challenging and unsustainable for the majority of patients [7]. Only $50 \%$ of patients with NAFLD will achieve histological improvement with weight loss and $\sim 77 \%$ 
will regain weight within three years after a lifestyle intervention $[7,8]$. While weight loss has remained fundamental to disease management, the benefits of exercise extend beyond weight loss alone. Exercise improves NAFLD independent of weight loss, however, the optimal exercise dose and pathophysiologic mechanisms by which exercise confers improvement in NAFLD remains unknown [9-12]. The practice guidelines for the management of NAFLD of the American Association for the Study of Liver Diseases (AASLD) recommends exercise; however, no specific approach or duration of exercise is otherwise detailed for practitioners [13]. The majority of exercise interventions in NAFLD have employed the American College of Sports Medicine physical activity guidelines for healthy adults—at least $150 \mathrm{~min}$ per week of moderate-intensity exercise or $75 \mathrm{~min}$ per week of vigorous intensity exercise, with resistance training twice per week on non-consecutive days [14]. These recommendations are appropriate given the current available evidence, however, individualized exercise prescriptions which lend the most optimal therapeutic benefit in NAFLD have yet to be identified. Our aim is to review and evaluate the available evidence of the independent effects of exercise in NAFLD and provide recommendations for improving exercise interventions as a treatment of NAFLD.

\section{Exercise Training in Patients with Nonalcoholic Fatty Liver Disease (NAFLD)}

\subsection{Aerobic Training}

The American College of Sports Medicine defines aerobic training as any activity using large muscle groups; is rhythmic in nature; and, can be continuously maintained [15]. Aerobic exercise training relies primarily on skeletal muscle's utilization of oxygen through aerobic respiration to produce energy, in the form of adenosine tri-phosphate or ATP [16]. The gold-standard for measuring physiologic adaptation to aerobic training is maximal aerobic capacity, $\mathrm{VO}_{2 \max }$, a measure of cardiorespiratory fitness. $\mathrm{VO}_{2}$ is a strong independent predictor of lifestyle-mediated reductions in intrahepatic fat in NAFLD [17]. Similarly, a recent 16-week study of supervised exercise training in NAFLD found that exercise-mediated improvements in $\mathrm{VO}_{2 \max }$ and liver fat occurred in the absence of weight loss; both were reversed after 12 months of exercise cessation [18]. Changes in $\mathrm{VO}_{2}$ and aerobic training-mediated improvements in NAFLD are theoretically linked. Thus, $\mathrm{VO}_{2 \text { max }}$ may serve both as a predictive biomarker of the exercise response and a biomarker of NAFLD disease severity. More studies will be required to address the underlying mechanisms between the improvements in exercise capacity and reductions in intrahepatic fat.

Nine randomized control trials and four uncontrolled studies have investigated the effects of aerobic training in NAFLD (Table 1) [9-11,19-28]. All of the studies included at least one aerobic training experimental group, with three studies containing multiple aerobic training groups of differing exercise intensities $[11,22,24]$. Maximum heart rate (MHR), heart rate reserve (HRR), maximal predicted heart rate (MPHR), metabolic equivalent of task (MET), or $\mathrm{VO}_{2 \max }$ were used to determine exercise intensity prescriptions-where intensities range from light to moderate (30-39\% of HRR, $57-63 \%$ of HRR, 2.0-3.9 METs, and 37-45\% of $\mathrm{VO}_{2 \max }$ ) moderate (40-59\% of HRR, $64-76 \%$ of HRR, $4.0-5.9$ METs, and $46-63 \%$ of $\mathrm{VO}_{2 \max }$ ), and vigorous (60-89\% of HRR, 77-95\% of HRR, 6.0-8.4 METs, and $64-90 \%$ of $\mathrm{VO}_{2 \max }$ ) [9-11,19-22,24,26,27,29]. Exercise modalities included recreational walking, treadmill running, cycle ergometry, cross-training, rowing, and rhythmic exercise [10,11,20-27]. Six studies used single modality exercise, while four studies used a multitude of exercise modalities [9-11,20-23,25-27]. Only two studies did not specify aerobic training. Exercise intervention lengths ranged from one week to one year, with the most commonly used duration as 16-weeks [9,19-23,25,26,28]. Frequency of exercise dosage ranged from three times per week for $30 \mathrm{~min}$ per day to seven times per week for $60 \mathrm{~min}$ per day $[19-21,25,26]$. Only three studies included more than 30 participants in at least one intervention group $[21,22,28]$. To date, all of the exercise intervention studies for NAFLD/NASH are limited by small sample size and insufficient samples size by which to assess improvement in hepatic fibrosis.

Alanine aminotransferase (ALT) and aspartate aminotransferase (AST) are enzymes used to monitor liver injury, and may be elevated in the blood of patients with NAFLD [30]. Although liver 
enzymes are insensitive markers of liver injury in NASH, a decrease in liver aminotransferases with treatment interventions may correlate histologic improvement in liver injury [31,32]. Overall, aerobic training reduces both systemic levels of ALT and AST [9-11,19,25,27,28]. Shamsoddini et al. showed that moderate-intensity treadmill running significantly improved mean ALT from $36.9 \pm 16.4 \mathrm{U} / \mathrm{L}$ to $24.4 \pm 7.2 \mathrm{U} / \mathrm{L}, p=0.002$; and improved AST from $29.7 \pm 9.0 \mathrm{U} / \mathrm{L}$ to $20.9 \pm 4.4 \mathrm{U} / \mathrm{L}, p=0.02$ in an eight-week aerobic training intervention in 10 ultrasound-confirmed NAFLD patients [10]. A larger nonrandomized trial by Sreenivasa Baba et al. indicated that in 59 participants with biopsy-proven $\mathrm{NASH}$, three-months of moderate-intensity aerobic exercise (walking, jogging, or rhythmic exercise) significantly reduced ALT (pre $104.0 \pm 40.5 \mathrm{U} / \mathrm{L}$, post $63.2 \pm 40.7 \mathrm{U} / \mathrm{L}, p<0.001$ ) and AST (pre $70.5 \pm 45.8 \mathrm{U} / \mathrm{L}$, post $41.5 \pm 22.6 \mathrm{U} / \mathrm{L}, p<0.001$ ) [27]. Additionally, Sreenivasa Baba et al. indicated that the effects of aerobic training on ALT and AST were independent of weight loss. Overall, the available evidence suggests that 8-12 weeks of aerobic training improves ALT and AST levels in patients with NAFLD or NASH. However, normal ALT values have been observed across the spectrum of NAFLD, and caution should be used when interpreting whether AST and ALT are appropriate surrogate markers for assessing changes in NAFLD with exercise training [33-35]. Additional non-invasive measurements, such as ultrasound-based techniques may provide a better method to monitor changes in liver fat when determining the efficacy of exercise on NAFLD progression [36,37].

Aerobic training significantly reduces hepatic fat content $3-43 \%$, with three studies indicating significant reductions independent of clinically meaningful weight loss [9-11,21-23,28]. However, it remains unclear whether intensity, volume, and/or frequency should be emphasized to optimize reductions in intrahepatic fat. A retrospective observational study by Kistler et al. of self-reported physical activity and its association with NAFLD histopathology suggests that vigorous intensity exercise, regardless of volume, reduces the risk of NAFLD severity [38]. However, Keating et al. investigated the role of exercise intensity and volume on hepatic fat in NAFLD; among 48 obese sedentary adults, differing exercise intensities and dosages had minimal nonsignificant changes on liver fat [24]. Testing the specific role of intensity and duration, Oh et al. indicated that, among 61 male NAFLD patients randomized to 12 weeks of moderate-intensity continuous cycling or vigorous-intensity interval cycling, both groups had similar significant reductions in intrahepatic fat (13.7\% in vigorous-intensity interval training, $14.3 \%$ in moderate-intensity continuous) despite differing exercise energy expenditure (180 kcal, $360 \mathrm{kcal})$ and exercise duration (13 $\mathrm{min}, 40 \mathrm{~min}$ ) [11]. Addressing the role of short-duration exercise, Haus et al. showed that vigorous-intensity treadmill running for seven consecutive days resulted in non-significant changes in intrahepatic fat levels in 13 MRI-confirmed NAFLD patients [25]. Thus, 12 weeks of moderate to vigorous intensity exercise, 3 days per week may be the minimum required dose to improve hepatic fat in NAFLD. Further studies evaluating differing intensities and frequencies within this framework on intrahepatic fat are needed to determine optimal prescriptions in NAFLD.

\subsection{Resistance Training}

Resistance training has been widely studied as exercise interventions in NAFLD, however it is perhaps the least understood out of all the types of exercise training for this indication. While aerobic training adaptations are typically measured via $\mathrm{VO}_{2}$, there are no gold standard measurements for assessing the resistance training adaptations. By targeting specific muscle fiber types (slow-twitch Type I, fast-twitch Type II) and energy systems (creatine-phosphate, glycolytic, aerobic), various resistance training prescriptions can elicit different physiologic effects and adaptations to skeletal muscle. This concept has not been well implemented in NAFLD, as specific resistance training protocols have not been aligned with muscle-related outcome measures. For example, improvements in lean muscle mass, absolute strength, or changes in skeletal muscle fiber type with resistance training protocols in NAFLD trials have rarely been measured or assessed as predictive outcomes. Thus, without confirmation that muscular endurance protocols led to changes in strength or muscle fiber type conversion; or muscular hypertrophy protocols led to increases in muscle mass; it is 
difficult to interpret whether the specific resistance training protocols actually lead to changes in NAFLD-specific outcomes. Moving forward, it will be important to link resistance training protocols with the intended effects in skeletal muscle phenotypes.

Seven randomized controlled trials and two non-randomized controlled trials measured the effects of resistance training in NAFLD [10,11,23,39-44]. Six studies used machine-based resistance training; one resistance machines and body weight; one utilized solely the participant's body weight; and, one weighted-belts [10,11,23,39-44]. Of the six studies, two utilized hypertrophy protocols; one study did not specify the \% 1-Repetition Maximum (RM) used; two did not mention the amount of repetitions prescribed; and, one did not specify the type of resistance training prescribed [10,11,23,39,42]. Most studies followed the general recommendation to increase resistance weight by $2-10 \%$ after one or two repetitions completed over the prescribed amount; however, three studies maintained resistance throughout the intervention $[14,23,42,44]$. Intervention durations have ranged from eight weeks to six months, with the most common duration as 12 weeks [10,11,39-44]. Resistance training protocols were conducted three times per week on nonconsecutive days to allow adequate time for muscle recovery and to minimize overtraining. As with aerobic training, sample sizes have been small, with only two studies containing at least one group with 30 or more participants $[39,44]$.

Similar to aerobic training, the current available evidence suggests that resistance training significantly reduces ALT and AST in NAFLD [10,39]. Reductions ranged from between 5.30 and 14.7 U/L in ALT and 2.76 to 5.1 U/L in AST. However, caution should be used when interpreting ALT and AST levels following resistance training; a previous study found significantly elevated liver enzymes up to seven days post-weightlifting in 15 men [45]. Five studies have indicated that resistance training reduces hepatic fat content $4 \%$ to $47.2 \%$, with three trials indicating reductions independent of weight loss $[10,11,40,41,43]$. Hallsworth et al. showed that in 19 MRI-confirmed NAFLD patients, eight-weeks of Precor circuit training three times per week for $45 \mathrm{~min}$ per session led to a $13 \%$ reduction in hepatic fat independent of weight loss [41]. In contrast, Hickman et al. found non-significant changes in liver fat following 6-months of circuit training [42]. Additionally, in patients with pre and post liver biopsies, Hickman et al. showed that resistance training led to non-significant changes in liver histology and NAFLD Activity Score, a histological scoring system for NAFLD. However, there was no control group as a comparator and only nine patients had follow-up liver biopsies. Overall, resistance training effects on NASH are comparable to aerobic training, but further studies are needed using differing resistance training protocols to delineate the optimal dosage.

\subsection{Aerobic and Resistance Combination Training}

Two clinical trials have utilized combination training in NASH and NAFLD [12,46]. Houghton et al. conducted a 12-week randomized trial in 24 biopsy-confirmed NASH patients; participants in the exercise arm completed three intervals of cycling for two min with one-minute rest in between each interval; followed by resistance exercises of hip and knee extension, horizontal row, chest press, vertical row, and knee extension [12]. The Borg rate of perceived exertion (RPE) scale was utilized to determine intensity [47]. The aerobic portion of the exercise protocol brought participants to an RPE between 16 and 18 (very hard), while the resistance portion brought participants to an RPE of between 14 and 16 (hard). This exercise regimen was conducted on three non-consecutive days per week, resulting in a $16 \%$ reduction in hepatic triglyceride content, independent of weight loss. There was no impact on ALT, AST, or metabolic variables. Shojaee-Moradie et al. conducted a 16-week randomized trial on 27 ultrasound-confirmed NAFLD patients. 15 participants in the exercise arm completed either gym-based or outdoor aerobic training, followed by resistance training-specific exercises that were not reported. Participants were brought to an intensity of $40-60 \%$ of HRR for $20 \mathrm{~min}$, which was slowly increased to an hour, four and five times per week for 16 weeks. Results indicated a significant inter-group reduction in intrahepatocellular fat by $19.6 \%$. Combination training may provide a novel opportunity to provide a catch-all exercise protocol for targeting NAFLD patients that have greater beneficial responses to either resistance training or aerobic training. 


\subsection{Novel Training Regimens}

Novel training modalities are exercise training considered neither aerobic nor resistance training. Two tested in NAFLD are acceleration [48] and hybrid training [49]. Acceleration training is a form of Whole-Body Vibration (WBV): energy from an external device is transferred via vibration to the human body at differing frequencies. Acceleration training entails "a physical stimulation effect on skeletal muscles by increasing gravitational acceleration with vibration" [48]. Hybrid training is the electrical stimulation of an agonist muscle to one being contracted voluntarily. Oh et al. conducted a 12-week acceleration training trial on 18 patients with ultrasound-confirmed NAFLD who showed an increase in serum ALT levels and liver fat after 12 weeks of lifestyle intervention. Acceleration training consists of three sessions: (1) a movement session with four stretches, at a frequency of $30 \mathrm{~Hz}$, amplitude low, for $30 \mathrm{~s}$ and two sets for each exercise; (2) a strength and power session, which utilized larger muscle group contraction at a frequency of $30-35 \mathrm{~Hz}$, amplitude low, for $30 \mathrm{~s}$ and two sets for each exercise; and, (3) a session focusing on massage, at a frequency of $40 \mathrm{~Hz}$, amplitude high, for $60 \mathrm{~s}$ and two sets for each exercise. Acceleration training sessions were conducted twice a week. Results indicated a reduction in hepatic fat by $8.7 \%$ and an improvement in ALT by $47.6 \%(95 \%$ CI, $33.0(20.0-53.0)$, to $22.5(18.0-43.0), p<0.05)$ independent of weight loss. There were no significant effects on metabolic variables or AST. Interestingly, cross-sectional area of skeletal muscle increased in the quadriceps. Interestingly, Oh et al. demonstrated that while lifestyle counseling through diet and physical activity should be prioritized, an exercise intervention might provide additional hepatic benefit for those patients unable to implement lifestyle modification.

Kawaguchi et al. conducted a 12-week study on 35 NAFLD patients that had previously shown an increase in ALT levels and hepatic steatosis after an initial lifestyle intervention. Participants were subsequently randomized into a hybrid training group $(n=12)$ or a control group $(n=23)$. During hybrid training, "electrodes were placed on the motor points of the medial and lateral hamstrings". Participants then performed 10 repetitions of three-second knee flexion and extension twice per week. Results indicated that hybrid training significant reduction ALT $(-14.1 \pm 5.8 \mathrm{IU} / \mathrm{mL}$, $p<0.05)$ and hepatic steatosis grade $(-0.67 \pm 0.19$ grade, $p<0.01)$ when compared to the controls. Hybrid and acceleration training may offer novel exercise options for NAFLD patients unable to participate in aerobic or resistance training interventions, including those with significant physical limitations that would otherwise exclude them from such training.

\section{Conclusions and Recommendations}

The benefits of exercise training in NAFLD are well established. Aerobic, resistance, combination, and novel training modalities improve systemic markers of liver function and intrahepatic fat in mild to advanced NAFLD. Despite the fact that the optimal exercise prescription is unclear, it is possible that no single exercise prescription is optimal. Ultimately, long-term adherence to exercise should be emphasized, which may be dictated by personal preferences for exercise intensity, frequency, duration, and modality. When considering exercise interventions, special attention should be given to improving cardiorespiratory fitness and improving musculoskeletal strength through progressive resistance training. However, NAFLD subjects should undergo proper preliminary screening measures including 12-led electrocardiography prior to initiating exercise prescriptions involving strenuous or vigorous intensities to ensure safety. Given the available evidence, 12 weeks of moderate to vigorous intensity aerobic exercise at $46-90 \%$ of $\mathrm{VO}_{2 \max }, 3$ days per week should be recommended to improve hepatic fat content. Additionally, we recommend 12 weeks of resistance training on nonconsecutive days using either skeletal muscle hypertrophy or strength training protocols prescribed by the American College of Sports Medicine. Further studies are warranted to determine the effects of exercise beyond steatosis, on histological markers of NAFLD in biopsy-proven disease. For patients with significant physical limitations, 12-weeks of acceleration and hybrid training may offer novel exercise training methods to improve intrahepatic fat, especially in patients that are unable to adopt lifestyle modification through counseling. Combination exercise interventions offer the potentially 
greatest promise by targeting both aerobic capacity and mediators of skeletal muscle that may directly alter liver health. Myokines (signaling proteins/peptides) are released from contracted skeletal muscle into the circulation where they communicate both locally and globally with tissues and organs including the liver [50]. While the role of myokines in NAFLD is unknown, preclinical models indicate that myokines, and particularly myokine IL-6, may modulate markers of liver injury and repair [51]. Myokine IL-6 directly communicates with the liver, regulating both hepatic glucose production and IL-8 expression [51,52]. Liver IL-8 expression is associated with the recruitment and activation of hepatic macrophages and stellate cells in patients with chronic liver disease, contributing to inflammation and fibrosis [53] Thus, myokine IL-6 regulation of liver IL-8 expression may be a likely mechanism of exercise mediated improvements in fibrosis in NAFLD. Moreover, myokine IL-6 has been shown to improve glucose uptake and fatty acid oxidation in skeletal muscle [54]. Given that exercise improves insulin sensitivity as well as glucose and lipid profiles, it is possible that myokine IL-6 is directly involved in these processes. Thus, understanding the role of myokines including, IL-6 in NAFLD, may identify future therapeutic targets that can be modified with specific exercise prescriptions. In support of the potential role of myokines, hybrid training, which contracts skeletal muscle through electrical stimulation, shows beneficial the effects on steatosis grade and liver enzymes. Maximizing skeletal muscle release of myokines and improving cardiorespiratory fitness may provide the one-two punch for the greatest benefits of exercise for patients with NAFLD. 
Table 1. Published Exercise Interventions in Nonalcoholic Fatty Liver Disease (2011-2017).

\begin{tabular}{|c|c|c|c|c|c|c|}
\hline Reference & Number of Patients & Patient Population & Study Design & Type of Exercise & $\begin{array}{l}\text { Relevant Liver } \\
\text { Measurements }\end{array}$ & Exercise Protocol \\
\hline $\begin{array}{l}\text { Sullivan et al. } \\
\quad 2012[9]\end{array}$ & 33 & $\begin{array}{l}\text { NAFLD patients. } \\
72 \% \text { female. }\end{array}$ & RCT & Aerobic & IHTG & $\begin{array}{c}\text { Exercise modality: Walking } \\
\text { Frequency of exercise: } 5 \times / \text { week, gradual increase to } 30-60 \mathrm{~min} / \text { session } \\
\text { Exercise intensity: } 45-55 \% \text { of } \mathrm{VO}_{2} \text { peak }\end{array}$ \\
\hline Pugh et al. 2013 [19] & 13 & NAFLD patients & RCT & Aerobic & $\begin{array}{l}\text { \% Liver fat; } \\
\text { ALT; AST }\end{array}$ & $\begin{array}{c}\text { Exercise modality: Unknown } \\
\text { Frequency of exercise: } 3 \text { to eventually } 5 \times / \text { week, } 30 \text { to eventually } \\
45 \mathrm{~min} / \text { session } \\
\text { Exercise intensity: } 30 \% \text { to eventually } 60 \% \text { of HRR }\end{array}$ \\
\hline Pugh et al. 2014 [20] & 31 & NAFLD patients & RCT & Aerobic & $\begin{array}{l}\text { \%Liver fat; } \\
\text { ALT; AST }\end{array}$ & $\begin{array}{c}\text { Exercise modality: Treadmill and cycle ergometer } \\
\text { Frequency of exercise: } 3 \text { to eventually } 5 \times / \text { week, } 30 \text { to eventually } \\
45 \mathrm{~min} / \text { session } \\
\text { Exercise intensity: } 30 \% \text { to eventually } 60 \% \text { HRR }\end{array}$ \\
\hline $\begin{array}{c}\text { Cuthbertson et al. } \\
\text { 2016 [21] }\end{array}$ & 69 & NAFLD patients & $\mathrm{RCT}$ & Aerobic & IHCL; ALT; AST & $\begin{array}{r}\text { Exercise modality: Treadmill, cross-trainer, bike ergometer, rower } \\
\text { Frequency of exercise: } 3 \text { to eventually } 5 \times / \text { week, } 30 \text { to eventually } \\
45 \mathrm{~min} / \text { session } \\
\text { Exercise intensity: } 30 \% \text { to eventually } 60 \% \text { HRR }\end{array}$ \\
\hline Fealy et al. 2012 [25] & 13 & NAFLD patients & Non-RCT & Aerobic & IHL; ALT & $\begin{array}{c}\text { Exercise modality: Treadmill walking } \\
\text { Frequency of exercise: } 60 \mathrm{~min} / \text { per day for } 7 \text { days in a row } \\
\text { Exercise intensity: } 80-85 \% \text { MHR }\end{array}$ \\
\hline Haus et al. 2013 [26] & 17 & NAFLD patients & Non-RCT & Aerobic & HTG & $\begin{array}{c}\text { Exercise modality: Treadmill walking } \\
\text { Frequency of exercise: } 60 \mathrm{~min} / \text { per day for } 7 \text { days in a row } \\
\text { Exercise intensity: } 80-85 \% \text { MHR }\end{array}$ \\
\hline $\begin{array}{l}\text { Sreenivasa Baba } \\
\text { et al. } 2006 \text { [27] }\end{array}$ & 65 & NASH patients & Non-RCT & Aerobic & TG; ALT; AST & $\begin{array}{l}\text { Exercise modality: Brisk walking, jogging or rhythmic aerobic exercises } \\
\text { set to beat music } \\
\text { Frequency of exercise: } 45 \mathrm{~min} / \text { day for at least } 5 \times / \text { week } \\
\text { Exercise intensity: } 60-70 \% \text { of MHR (for at least } 20 \mathrm{~min} \text { ) }\end{array}$ \\
\hline $\begin{array}{l}\text { Zhang et al. } \\
2016 \text { [22] }\end{array}$ & 220 & $\begin{array}{l}\text { NAFLD patients. } \\
68 \% \text { female. }\end{array}$ & RCT & Aerobic & IHTG & $\begin{array}{c}\text { Vigorous-moderate: } \\
\text { Exercise modality: Treadmill } \\
\text { Frequency of exercise: } 5 \times / \text { week, } 30 \mathrm{~min} / \mathrm{session} . \\
\text { Exercise intensity: } 65-80 \% \text { of MPHR for 6-months (8-10 METs), } 45-55 \% \text { o } \\
\text { MPHR for last } 6 \text { months (3-6 METs) } \\
\text { Moderate intensity: } \\
\text { Exercise modality: Treadmill } \\
\text { Frequency of exercise: } 5 \times / \text { week, } 30 \text { min } / \text { session. } \\
\text { Exercise intensity: } 45-55 \% \text { of MPHR for } 12 \text { months (3-6 METs) }\end{array}$ \\
\hline $\begin{array}{c}\text { Khaoshbaten et al. } \\
2013[28]\end{array}$ & 90 & $\begin{array}{c}\text { NAFLD patients. } \\
63 \% \text { male. }\end{array}$ & Non-RCT & Aerobic & TG; ALT; AST & No specified exercise prescription \\
\hline
\end{tabular}


Table 1. Cont.

\begin{tabular}{|c|c|c|c|c|c|c|}
\hline Reference & Number of Patients & Patient Population & Study Design & Type of Exercise & $\begin{array}{l}\text { Relevant Liver } \\
\text { Measurements }\end{array}$ & Exercise Protocol \\
\hline Bacchi et al. 2013 [23] & 40 & $\begin{array}{c}\text { Type } 2 \text { diabetes } \\
\text { patients with NAFLD }\end{array}$ & RCT & $\begin{array}{l}\text { Aerobic and } \\
\text { Resistance }\end{array}$ & TG; ALT; AST & $\begin{array}{c}\text { Aerobic: } \\
\text { Exercise modality: Treadmill, cycle, elliptical } \\
\text { Frequency of exercise: } 3 \times / \text { week, } 60 \mathrm{~min} / \mathrm{session} \\
\text { Exercise intensity: } 60-65 \% \mathrm{HRR} \\
\text { Resistance } \\
\text { Exercise modality: } 9 \text { different exercises involving major muscle groups } \\
\text { Frequency of exercise: } 3 \times / \text { week. } 3 \text { sets } / 10 \mathrm{reps} \text { per exercise with } 1 \text { min recovery } \\
\text { between sets } \\
\text { Exercise intensity: } 70-80 \% \text { of } 1 \mathrm{RM} \\
\end{array}$ \\
\hline $\begin{array}{l}\text { Shamsoddini et al. } \\
2015 \text { [10] }\end{array}$ & 30 & $\begin{array}{l}\text { NAFLD patients. } \\
100 \% \text { male. }\end{array}$ & RCT & $\begin{array}{l}\text { Aerobic and } \\
\text { Resistance }\end{array}$ & Liver fat; ALT; AST & $\begin{array}{c}\text { Aerobic } \\
\text { Exercise modality: Treadmill } \\
\text { Frequency of exercise: } 3 \times / \text { week, } 45 \mathrm{~min} / \text { per session } \\
\text { Exercise intensity: } 60-75 \% \mathrm{MHR} \\
\text { Resistance } \\
\text { Exercise modality: Circuit training } \\
\text { Frequency of exercise: } 3 \times / \text { week, } 2 \text { to eventually } 3 \text { circuits } / \text { per session, } 90 \mathrm{~s} \text { rest } \\
\text { in between circuits } \\
\text { Exercise intensity: } 50 \% \text { to eventually } 70 \% \text { of } 1 \mathrm{RM} \\
\end{array}$ \\
\hline Oh et al. 2017 [11] & 61 & $\begin{array}{l}\text { NAFLD patients. } \\
100 \% \text { male. }\end{array}$ & RCT & $\begin{array}{l}\text { Aerobic and } \\
\text { Resistance }\end{array}$ & $\begin{array}{l}\text { Liver fat; IHL; TG; } \\
\text { ALT; AST }\end{array}$ & $\begin{array}{c}\text { High-intensity Aerobic: } \\
\text { Exercise modality: Cycling } \\
\text { Frequency of exercise: } 3 \times / \text { week, } 3 \text { sets of 3-min cycling sessions, } 2 \text { min rest } \\
\left.\text { (at a lower } \mathrm{VO}_{2} \mathrm{Max}\right) \\
\text { Exercise intensity: } 80-85 \% \mathrm{VO}_{2} \mathrm{Max}^{2}\left(50 \% \mathrm{VO}_{2} \mathrm{Max} \text { during rest) }\right. \\
\text { Moderate-intensity continuous training: } \\
\text { Exercise modality: Cycling } \\
\text { Frequency of exercise: } 3 \times / \text { week, } 40 \mathrm{~min} / \text { session } \\
\text { Exercise intensity: } 60-65 \% \mathrm{VO}_{2} \mathrm{Max} \\
\text { Resistance: } \\
\text { Exercise modality: Sit-ups, leg presses, leg extensions, leg curls, chest presses, } \\
\text { seated rows, and pull-downs } \\
\text { Frequency of exercise: } 3 \times / \text { week } \\
\text { Exercise intensity: No specific mention }\end{array}$ \\
\hline Damor et al. 2013 [43] & 32 & $\begin{array}{l}\text { NAFLD patients. } \\
71 \% \text { male. }\end{array}$ & Non-RCT & Resistance & $\begin{array}{l}\text { Liver fat; TG; } \\
\text { ALT; AST }\end{array}$ & $\begin{array}{l}\text { Exercise modality: Body weight exercise-flexion at biceps, triceps, and hip } \\
\text { flexion, knee extension and heel rise. } \\
\text { Frequency of exercise: } 3 \times / \text { week, } 2 \text { sets } / 10 \text { reps } \\
\text { Exercise intensity: Starting at } 1 \mathrm{~kg} \text { less than } 3 \mathrm{RM}, .5 \mathrm{~kg} \text { was added after each week }\end{array}$ \\
\hline Zelber-Sagi et al. 2014 [39] & 82 & NAFLD patients & RCT & Resistance & TG; ALT; AST & $\begin{array}{l}\text { Exercise modality: Exercises included-leg press, leg extension, leg curl, seated } \\
\text { chest press, seated rowing, latissimus pull down, biceps curl and shoulder press } \\
\text { Frequency of exercise: } 3 \times / \text { week, } 3 \text { sets } / 8-12 \text { reps with } 1-2 \text { min rest between sets, } \\
\text { for a total duration of about } 40 \text { min. } \\
\text { Exercise intensity: } \% 1 \text { RM unspecified, load gradually increased } 2-10 \% \text { per week }\end{array}$ \\
\hline
\end{tabular}


Table 1. Cont.

\begin{tabular}{|c|c|c|c|c|c|c|}
\hline Reference & Number of Patients & Patient Population & Study Design & Type of Exercise & $\begin{array}{l}\text { Relevant Liver } \\
\text { Measurements }\end{array}$ & Exercise Protocol \\
\hline $\begin{array}{l}\text { Takahashi et al. } \\
2015 \text { [44] }\end{array}$ & 53 & NAFLD patients & Non-RCT & Resistance & Liver fat & $\begin{array}{l}\text { Exercise modality: Body weight-slow-controlled push-ups and squat } \\
\text { Frequency of exercise: } 3 \times / \text { week, } 3 \text { sets } / 10 \text { push-ups and } 3 \text { sets } / 10 \text { squats } \\
\text { at } 1 \text {-min intervals per set over a period of } 20-30 \mathrm{~min} \\
\text { Exercise intensity: N/A }\end{array}$ \\
\hline $\begin{array}{c}\text { Jakovljevic et al. } \\
2013 \text { [40] }\end{array}$ & 17 & $\begin{array}{l}\text { NAFLD patients. } \\
71 \% \text { male. }\end{array}$ & RCT & Resistance & TG; ALT & $\begin{array}{c}\text { Exercise modality: Circuit training } \\
\text { Frequency of exercise: } 3 \times / \text { week, } 2 \text { to eventually } 3 \text { circuits, } 45-60 \text { min } \\
\text { Exercise intensity: } 50 \% \text { to eventually } 70 \% 1 \mathrm{RM}\end{array}$ \\
\hline $\begin{array}{l}\text { Hallsworth et al. } \\
\quad 2011[41]\end{array}$ & 19 & NAFLD patients & RCT & Resistance & IHL & $\begin{array}{c}\text { Exercise modality: Circuit training } \\
\text { Frequency of exercise: } 3 \times / \text { week, } 2 \text { to eventually } 3 \text { circuits, } 45-60 \mathrm{~min} \\
\text { Exercise intensity: } 50 \% \text { to eventually } 70 \% 1 \mathrm{RM}\end{array}$ \\
\hline $\begin{array}{c}\text { Hickman et al. } 2013 \\
\text { [42] }\end{array}$ & 21 & $\begin{array}{l}\text { NAFLD and NASH } \\
\text { patients }\end{array}$ & RCT & Resistance & ALT; Fasting TG & $\begin{array}{c}\text { Exercise modality: Circuit training } \\
\text { Frequency of exercise: } 3 \times / \text { week, } 1 \text { circuit to eventually } 5 \text { circuits, } 12 \text { to } \\
\text { eventually } 60 \mathrm{~min} / \text { session } \\
\text { Exercise intensity: Fixed at } 50 \% \text { of } 1 \mathrm{RM}\end{array}$ \\
\hline $\begin{array}{l}\text { Houghton et al. } \\
2017 \text { [12] }\end{array}$ & 24 & NASH patients & RCT & Combination & HTG; ALT; AST & $\begin{array}{l}\text { Exercise modality: High-intensity interval training (cycling) and } \\
\text { resistance training } \\
\text { Frequency of exercise: } 3 \times / \text { week. } 45-60 \mathrm{~min} / \text { session } \\
\text { Exercise intensity: Cycling at RPE between } 16 \text { to } 18 \text {, resistance exercise at } \\
\text { RPE between } 14 \text { to } 16\end{array}$ \\
\hline $\begin{array}{l}\text { Shojaee-Moradie } \\
\text { et al. } 2016 \text { [46] }\end{array}$ & 27 & NAFLD patients & RCT & Combination & $\begin{array}{l}\text { IHCL; TG; } \\
\text { ALT; AST }\end{array}$ & $\begin{array}{c}\text { Exercise modality: Gym or outdoor-based aerobic training and resistance } \\
\text { training } \\
\text { Frequency of exercise: } 4-5 \times / \text { week, } 20 \text { to eventually } 60 \mathrm{~min} \\
\text { Exercise intensity: } 40-60 \% \text { HRR }\end{array}$ \\
\hline Oh et al. 2014 [48] & 18 & NAFLD patients & Non-RCT & $\begin{array}{l}\text { Acceleration } \\
\text { training }\end{array}$ & $\begin{array}{l}\text { Liver fat; TG; } \\
\text { ALT; AST }\end{array}$ & $\begin{array}{c}\text { Exercise modality: Acceleration training } \\
\text { Frequency of exercise: } 2 \times / \text { week, } 40 \mathrm{~min} / \mathrm{session} \\
\text { Exercise intensity: Movement session with four stretches, at a frequency } \\
\text { of } 30 \mathrm{~Hz} \text {, amplitude low, for } 30 \mathrm{~s} \text { and two sets for each exercise; Strength } \\
\text { and power session which utilized larger muscle group contraction, at a } \\
\text { frequency of } 30-35 \mathrm{~Hz} \text {, amplitude low, for } 30 \mathrm{~s} \text { and two sets for each } \\
\text { exercise; Massage session at a frequency of } 40 \mathrm{~Hz} \text {, amplitude high, for } 60 \mathrm{~s} \\
\text { and two sets for each exercise. }\end{array}$ \\
\hline $\begin{array}{c}\text { Kawaguchi et al. } \\
2011 \text { [49] }\end{array}$ & 35 & NAFLD patients & Non-RCT & Hybrid training & TG; ALT; AST & $\begin{array}{l}\text { Exercise modality: Hybrid training. } \\
\text { Frequency of exercise: } 2 \text { x/week, } 10 \text { sets } / 10 \text { reciprocal 3-s knee flexion and } \\
\text { extension contractions, } 1 \mathrm{~min} \text { rest between sets, } 19 \mathrm{~min} / \text { day } \\
\text { Exercise intensity: Electrical stimulation intensity was set at a level of } \\
20-25 \text { consecutive knee flexions and extensions }\end{array}$ \\
\hline
\end{tabular}

RCT: Randomized control trial; Non-RCT: Non-randomized control trial; TG: Triglycerides; HTG: Hepatic triglyceride content; IHTG: Intrahepatic triglyceride content;

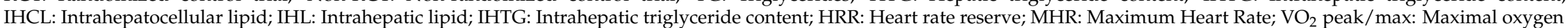
consumption; RM: Repetition maximum; RPE: Rate of perceived exertion. 
Conflicts of Interest: The authors declare no conflict of interest.

\section{References}

1. Bellentani, S.; Scaglioni, F.; Marino, M.; Bedogni, G. Epidemiology of non-alcoholic fatty liver disease. Dig. Dis. 2010, 28, 155-161. [CrossRef] [PubMed]

2. Heidari, Z.; Gharebaghi, A. Prevalence of Non Alcoholic Fatty Liver Disease and its Association with Diabetic Nephropathy in Patients with Type 2 Diabetes Mellitus. J. Clin. Diagn. Res. 2017, 11, OC04-OC07. [CrossRef] [PubMed]

3. Angulo, P.; Kleiner, D.E.; Dam-Larsen, S.; Adams, L.A.; Bjornsson, E.S.; Charatcharoenwitthaya, P.; Mills, P.R.; Keach, J.C.; Lafferty, H.D.; Stahler, A.; et al. Liver Fibrosis, but No Other Histologic Features, is Associated with Long-term Outcomes of Patients with Nonalcoholic Fatty Liver Disease. Gastroenterology 2015, 149, 389-397. [CrossRef] [PubMed]

4. Thoma, C.; Day, C.P.; Trenell, M.I. Lifestyle interventions for the treatment of non-alcoholic fatty liver disease in adults: A systematic review. J. Hepatol. 2012, 56, 255-266. [CrossRef] [PubMed]

5. Promrat, K.; Kleiner, D.E.; Niemeier, H.M.; Jackvony, E.; Kearns, M.; Wands, J.R.; Fava, J.L.; Wing, R.R. Randomized controlled trial testing the effects of weight loss on nonalcoholic steatohepatitis. Hepatology 2010, 51, 121-129. [CrossRef] [PubMed]

6. Vilar-Gomez, E.; Martinez-Perez, Y.; Calzadilla-Bertot, L.; Torres-Gonzalez, A.; Gra-Oramas, B.; Gonzalez-Fabian, L.; Friedman, S.L.; Diago, M.; Romero-Gomez, M. Weight Loss Through Lifestyle Modification Significantly Reduces Features of Nonalcoholic Steatohepatitis. Gastroenterology 2015, 149, 367-378. [CrossRef] [PubMed]

7. Dudekula, A.; Rachakonda, V.; Shaik, B.; Behari, J. Weight loss in nonalcoholic Fatty liver disease patients in an ambulatory care setting is largely unsuccessful but correlates with frequency of clinic visits. PLoS ONE 2014, 9. [CrossRef] [PubMed]

8. Musso, G.; Gambino, R.; Cassader, M.; Pagano, G. A meta-analysis of randomized trials for the treatment of nonalcoholic fatty liver disease. Hepatology 2010, 52, 79-104. [CrossRef] [PubMed]

9. Sullivan, S.; Kirk, E.P.; Mittendorfer, B.; Patterson, B.W.; Klein, S. Randomized trial of exercise effect on intrahepatic triglyceride content and lipid kinetics in nonalcoholic fatty liver disease. Hepatology 2012, 55, 1738-1745. [CrossRef] [PubMed]

10. Shamsoddini, A.; Sobhani, V.; Ghamar Chehreh, M.E.; Alavian, S.M.; Zaree, A. Effect of Aerobic and Resistance Exercise Training on Liver Enzymes and Hepatic Fat in Iranian Men With Nonalcoholic Fatty Liver Disease. Hepat. Mon. 2015, 15, e31434. [CrossRef] [PubMed]

11. Oh, S.; So, R.; Shida, T.; Matsuo, T.; Kim, B.; Akiyama, K.; Isobe, T.; Okamoto, Y.; Tanaka, K.; Shoda, J. High-Intensity Aerobic Exercise Improves Both Hepatic Fat Content and Stiffness in Sedentary Obese Men with Nonalcoholic Fatty Liver Disease. Sci. Rep. 2017, 7, 43029. [CrossRef] [PubMed]

12. Houghton, D.; Thoma, C.; Hallsworth, K.; Cassidy, S.; Hardy, T.; Burt, A.D.; Tiniakos, D.; Hollingsworth, K.G.; Taylor, R.; Day, C.P.; et al. Exercise Reduces Liver Lipids and Visceral Adiposity in Patients With Nonalcoholic Steatohepatitis in a Randomized Controlled Trial. Clin. Gastroenterol. Hepatol. 2017, 15, 96-102. [CrossRef] [PubMed]

13. Chalasani, N.; Younossi, Z.; Lavine, J.E.; Diehl, A.M.; Brunt, E.M.; Cusi, K.; Charlton, M.; Sanyal, A.J. The diagnosis and management of non-alcoholic fatty liver disease: Practice guideline by the American Gastroenterological Association, American Association for the Study of Liver Diseases, and American College of Gastroenterology. Gastroenterology 2012, 142, 1592-1609. [CrossRef] [PubMed]

14. American College of Sports Medicine. American College of Sports Medicine position stand. Progression models in resistance training for healthy adults. Med. Sci. Sports. Exerc. 2009, 41, 687-708. [CrossRef]

15. American College of Sports Medicine. ACSM's Guidelines for Exercise Testing and Prescription, 6th ed.; Lippincott Williams \& Wilkins: Philadelphia, PA, USA, 2000.

16. Patel, H.; Alkhawam, H.; Madanieh, R.; Shah, N.; Kosmas, C.E.; Vittorio, T.J. Aerobic vs anaerobic exercise training effects on the cardiovascular system. World J. Cardiol. 2017, 9, 134-138. [CrossRef] [PubMed] 
17. Kantartzis, K.; Thamer, C.; Peter, A.; Machann, J.; Schick, F.; Schraml, C.; Konigsrainer, A.; Konigsrainer, I.; Krober, S.; Niess, A.; et al. High cardiorespiratory fitness is an independent predictor of the reduction in liver fat during a lifestyle intervention in non-alcoholic fatty liver disease. Gut 2009, 58, 1281-1288. [CrossRef] [PubMed]

18. Pugh, C.J.; Sprung, V.S.; Jones, H.; Richardson, P.; Shojaee-Moradie, F.; Umpleby, A.M.; Green, D.J.; Cable, N.T.; Trenell, M.I.; Kemp, G.J.; et al. Exercise-induced improvements in liver fat and endothelial function are not sustained 12 months following cessation of exercise supervision in nonalcoholic fatty liver disease. Int. J. Obes. (Lond.) 2016, 40, 1927-1930. [CrossRef] [PubMed]

19. Pugh, C.J.; Cuthbertson, D.J.; Sprung, V.S.; Kemp, G.J.; Richardson, P.; Umpleby, A.M.; Green, D.J.; Cable, N.T.; Jones, $\mathrm{H}$. Exercise training improves cutaneous microvascular function in nonalcoholic fatty liver disease. Am. J. Physiol. Endocrinol. Metab. 2013, 305, E50-E58. [CrossRef] [PubMed]

20. Pugh, C.J.; Spring, V.S.; Kemp, G.J.; Richardson, P.; Shojaee-Moradie, F.; Umpleby, A.M.; Green, D.J.; Cable, N.T.; Jones, H.; Cuthbertson, D.J. Exercise training reverses endothelial dysfunction in nonalcoholic fatty liver disease. Am. J. Physiol. Heart Circ. Physiol. 2014, 307, H1298-H1306. [CrossRef] [PubMed]

21. Cuthbertson, D.J.; Shojaee-Moradie, F.; Sprung, V.S.; Jones, H.; Pugh, C.J.; Richardson, P.; Kemp, G.J.; Barrett, M.; Jackson, N.C.; Thomas, E.L.; et al. Dissociation between exercise-induced reduction in liver fat and changes in hepatic and peripheral glucose homoeostasis in obese patients with non-alcoholic fatty liver disease. Clin. Sci. (Lond.) 2016, 130, 93-104. [CrossRef] [PubMed]

22. Zhang, H.J.; He, J.; Pan, L.L.; Ma, Z.M.; Han, C.K.; Chen, C.S.; Chen, Z.; Han, H.W.; Chen, S.; Sun, Q.; et al. Effects of Moderate and Vigorous Exercise on Nonalcoholic Fatty Liver Disease: A Randomized Clinical Trial. JAMA Intern. Med. 2016, 176, 1074-1082. [CrossRef] [PubMed]

23. Bacchi, E.; Negri, C.; Targher, G.; Faccioli, N.; Lanza, M.; Zoppini, G.; Zanolin, E.; Schena, F.; Bonora, E.; Moghetti, P. Both resistance training and aerobic training reduce hepatic fat content in type 2 diabetic subjects with nonalcoholic fatty liver disease (the RAED2 Randomized Trial). Hepatology 2013, 58, 1287-1295. [CrossRef] [PubMed]

24. Keating, S.E.; Hackett, D.A.; Parker, H.M.; O'Connor, H.T.; Gerofi, J.A.; Sainsbury, A.; Baker, M.K.; Chuter, V.H.; Caterson, I.D.; George, J.; et al. Effect of aerobic exercise training dose on liver fat and visceral adiposity. J. Hepatol. 2015, 63, 174-182. [CrossRef] [PubMed]

25. Fealy, C.E.; Haus, J.M.; Solomon, T.P.; Pagadala, M.; Flask, C.A.; McCullough, A.J.; Kirwan, J.P. Short-term exercise reduces markers of hepatocyte apoptosis in nonalcoholic fatty liver disease. J. Appl. Physiol. 2012, 113, 1-6. [CrossRef] [PubMed]

26. Haus, J.M.; Solomon, T.P.; Kelly, K.R.; Fealy, C.E.; Kullman, E.L.; Scelsi, A.R.; Lu, L.; Pagadala, M.R.; McCullough, A.J.; Flask, C.A.; et al. Improved hepatic lipid composition following short-term exercise in nonalcoholic fatty liver disease. J. Clin. Endocrinol. Metab. 2013, 98, E1181-E1188. [CrossRef] [PubMed]

27. Sreenivasa Baba, C.; Alexander, G.; Kalyani, B.; Pandey, R.; Rastogi, S.; Pandey, A.; Choudhuri, G. Effect of exercise and dietary modification on serum aminotransferase levels in patients with nonalcoholic steatohepatitis. J. Gastroenterol. Hepatol. 2006, 21, 191-198. [CrossRef] [PubMed]

28. Khaoshbaten, M.; Gholami, N.; Sokhtehzari, S.; Monazami, A.H.; Nejad, M.R. The effect of an aerobic exercise on serum level of liver enzymes and liver echogenicity in patients with non alcoholic fatty liver disease. Gastroenterol. Hepatol. Bed Bench 2013, 6, S112-S116. [PubMed]

29. Garber, C.E.; Blissmer, B.; Deschenes, M.R.; Franklin, B.A.; Lamonte, M.J.; Lee, I.M.; Nieman, D.C.; Swain, D.P.; American College of Sports Medicine. American College of Sports Medicine position stand. Quantity and quality of exercise for developing and maintaining cardiorespiratory, musculoskeletal, and neuromotor fitness in apparently healthy adults: Guidance for prescribing exercise. Med. Sci. Sports Exerc. 2011, 43, 1334-1359. [CrossRef] [PubMed]

30. Sattar, N.; Forrest, E.; Preiss, D. Non-alcoholic fatty liver disease. BMJ 2014, 349, g4596. [CrossRef] [PubMed]

31. Sanyal, A.J.; Chalasani, N.; Kowdley, K.V.; McCullough, A.; Diehl, A.M.; Bass, N.M.; Neuschwander-Tetri, B.A.; Lavine, J.E.; Tonascia, J.; Unalp, A.; et al. Pioglitazone, vitamin E, or placebo for nonalcoholic steatohepatitis. N. Engl. J. Med. 2010, 362, 1675-1685. [CrossRef] [PubMed]

32. Neuschwander-Tetri, B.A.; Loomba, R.; Sanyal, A.J.; Lavine, J.E.; Van Natta, M.L.; Abdelmalek, M.F.; Chalasani, N.; Dasarathy, S.; Diehl, A.M.; Hameed, B.; et al. Farnesoid X nuclear receptor ligand obeticholic acid for non-cirrhotic, non-alcoholic steatohepatitis (FLINT): A multicentre, randomised, placebo-controlled trial. Lancet 2015, 385, 956-965. [CrossRef] 
33. Mofrad, P.; Contos, M.J.; Haque, M.; Sargeant, C.; Fisher, R.A.; Luketic, V.A.; Sterling, R.K.; Shiffman, M.L.; Stravitz, R.T.; Sanyal, A.J. Clinical and histologic spectrum of nonalcoholic fatty liver disease associated with normal ALT values. Hepatology 2003, 37, 1286-1292. [CrossRef] [PubMed]

34. Portillo-Sanchez, P.; Bril, F.; Maximos, M.; Lomonaco, R.; Biernacki, D.; Orsak, B.; Subbarayan, S.; Webb, A.; Hecht, J.; Cusi, K. High Prevalence of Nonalcoholic Fatty Liver Disease in Patients With Type 2 Diabetes Mellitus and Normal Plasma Aminotransferase Levels. J. Clin. Endocrinol. Metab. 2015, 100, 2231-2238. [CrossRef] [PubMed]

35. Nascimbeni, F.; Pais, R.; Bellentani, S.; Day, C.P.; Ratziu, V.; Loria, P.; Lonardo, A. From NAFLD in clinical practice to answers from guidelines. J. Hepatol. 2013, 59, 859-871. [CrossRef] [PubMed]

36. Ballestri, S.; Romagnoli, D.; Nascimbeni, F.; Francica, G.; Lonardo, A. Role of ultrasound in the diagnosis and treatment of nonalcoholic fatty liver disease and its complications. Expert Rev. Gastroenterol. Hepatol. 2015, 9, 603-627. [CrossRef] [PubMed]

37. Ballestri, S.; Nascimbeni, F.; Baldelli, E.; Marrazzo, A.; Romagnoli, D.; Targher, G.; Lonardo, A. Ultrasonographic fatty liver indicator detects mild steatosis and correlates with metabolic/histological parameters in various liver diseases. Metabolism 2017, 72, 57-65. [CrossRef] [PubMed]

38. Kistler, K.D.; Brunt, E.M.; Clark, J.M.; Diehl, A.M.; Sallis, J.F.; Schwimmer, J.B.; NASH CRN Research Group. Physical activity recommendations, exercise intensity, and histological severity of nonalcoholic fatty liver disease. Am. J. Gastroenterol. 2011, 106, 460-468. [CrossRef] [PubMed]

39. Zelber-Sagi, S.; Buch, A.; Yeshua, H.; Vaisman, N.; Webb, M.; Harari, G.; Kis, O.; Fliss-Isakov, N.; Izkhakov, E.; Halpern, Z.; et al. Effect of resistance training on non-alcoholic fatty-liver disease a randomized-clinical trial. World J. Gastroenterol. 2014, 20, 4382-4392. [CrossRef] [PubMed]

40. Jakovljevic, D.G.; Hallsworth, K.; Zalewski, P.; Thoma, C.; Klawe, J.J.; Day, C.P.; Newton, J.; Trenell, M.I. Resistance exercise improves autonomic regulation at rest and haemodynamic response to exercise in non-alcoholic fatty liver disease. Clin. Sci. (Lond.) 2013, 125, 143-149. [CrossRef] [PubMed]

41. Hallsworth, K.; Fattakhova, G.; Hollingsworth, K.G.; Thoma, C.; Moore, S.; Taylor, R.; Day, C.P.; Trenell, M.I. Resistance exercise reduces liver fat and its mediators in non-alcoholic fatty liver disease independent of weight loss. Gut 2011, 60, 1278-1283. [CrossRef] [PubMed]

42. Hickman, I.; Byrne, N.; Croci, I.; Chachay, V.; Clouston, A. A Pilot Randomised Study of the Metabolic and Histological Effects of Exercise in Non-alcoholic Steatohepatitis. Diabetes Metab. 2013, 4, 1-10. [CrossRef]

43. Damor, K.; Mittal, K.; Bhalla, A.; Sood, R.; Pandey, R.; Guleria, R.; Luthra, K.; Vikram, N. Effect of Progressive Resistance Exercise Training on Hepatic Fat in Asian Indians with Non-Alcoholic Fatty Liver Disease. Br. J. Med. Med. Res. 2013, 4, 114-124. [CrossRef]

44. Takahashi, A.; Abe, K.; Usami, K.; Imaizumi, H.; Hayashi, M.; Okai, K.; Kanno, Y.; Tanji, N.; Watanabe, H.; Ohira, H. Simple Resistance Exercise helps Patients with Non-alcoholic Fatty Liver Disease. Int. J. Sports Med. 2015, 36, 848-852. [CrossRef] [PubMed]

45. Pettersson, J.; Hindorf, U.; Persson, P.; Bengtsson, T.; Malmqvist, U.; Werkstrom, V.; Ekelund, M. Muscular exercise can cause highly pathological liver function tests in healthy men. Br. J. Clin. Pharmacol. 2008, 65, 253-259. [CrossRef] [PubMed]

46. Shojaee-Moradie, F.; Cuthbertson, D.J.; Barrett, M.; Jackson, N.C.; Herring, R.; Thomas, E.L.; Bell, J.; Kemp, G.J.; Wright, J.; Umpleby, A.M. Exercise Training Reduces Liver Fat and Increases Rates of VLDL Clearance But Not VLDL Production in NAFLD. J. Clin. Endocrinol. Metab. 2016, 101, 4219-4228. [CrossRef] [PubMed]

47. Borg, G.A. Psychophysical bases of perceived exertion. Med. Sci. Sports Exerc. 1982, 14, 377-381. [CrossRef] [PubMed]

48. Oh, S.; Shida, T.; Sawai, A.; Maruyama, T.; Eguchi, K.; Isobe, T.; Okamoto, Y.; Someya, N.; Tanaka, K.; Arai, E.; et al. Acceleration training for managing nonalcoholic fatty liver disease: A pilot study. Ther. Clin. Risk Manag. 2014, 10, 925-936. [CrossRef] [PubMed]

49. Kawaguchi, T.; Shiba, N.; Maeda, T.; Matsugaki, T.; Takano, Y.; Itou, M.; Sakata, M.; Taniguchi, E.; Nagata, K.; Sata, M. Hybrid training of voluntary and electrical muscle contractions reduces steatosis, insulin resistance, and IL-6 levels in patients with NAFLD: A pilot study. J. Gastroenterol. 2011, 46, 746-757. [CrossRef] [PubMed]

50. Pedersen, B.K.; Fischer, C.P. Beneficial health effects of exercise-The role of IL-6 as a myokine. Trends Pharmacol. Sci. 2007, 28, 152-156. [CrossRef] [PubMed] 
51. Pedersen, L.; Pilegaard, H.; Hansen, J.; Brandt, C.; Adser, H.; Hidalgo, J.; Olesen, J.; Pedersen, B.K.; Hojman, P. Exercise-induced liver chemokine CXCL-1 expression is linked to muscle-derived interleukin-6 expression. J. Physiol. 2011, 589, 1409-1420. [CrossRef] [PubMed]

52. Febbraio, M.A.; Hiscock, N.; Sacchetti, M.; Fischer, C.P.; Pedersen, B.K. Interleukin-6 is a novel factor mediating glucose homeostasis during skeletal muscle contraction. Diabetes 2004, 53, 1643-1648. [CrossRef] [PubMed]

53. Zimmermann, H.W.; Seidler, S.; Gassler, N.; Nattermann, J.; Luedde, T.; Trautwein, C.; Tacke, F. Interleukin-8 is activated in patients with chronic liver diseases and associated with hepatic macrophage accumulation in human liver fibrosis. PLoS ONE 2011, 6, e21381. [CrossRef] [PubMed]

54. Pedersen, B.K.; Febbraio, M.A. Muscle as an endocrine organ: Focus on muscle-derived interleukin-6. Physiol. Rev. 2008, 88, 1379-1406. [CrossRef] [PubMed]

(C) 2017 by the authors. Licensee MDPI, Basel, Switzerland. This article is an open access article distributed under the terms and conditions of the Creative Commons Attribution (CC BY) license (http://creativecommons.org/licenses/by/4.0/). 